\title{
The American Psychiatric Association Treatment Guideline for Major Depressive Disorder: process and content
}

Alan J Gelenberg

From $1^{\text {st }}$ International Congress on Neurobiology and Clinical Psychopharmacology and European Psychiatric Association Conference on Treatment Guidance

Thessaloniki, Greece. 19-22 November 2009

Dr. Gelenberg has been a member of the American Psychiatric Association's Workgroup on the Treatment Guideline for Major Depressive Disorder since its inception in the 1980s. For the past several years, he has chaired the workgroup writing the 3rd edition, which should be published in late 2009. This talk will review the history of this work, discuss guidelines broadly in the current era of evidence-based medicine, define epistemology and its relevance, and describe the process of developing a treatment guideline-the scientific and the political. The talk will then outline recent changes in the treatment of depression-medications, stimulation approaches, psychotherapy, and others. It will conclude with a preview of the future in this area.

Published: 22 April 2010

doi:10.1186/1744-859X-9-S1-S46

Cite this article as: Gelenberg: The American Psychiatric Association

Treatment Guideline for Major Depressive Disorder: process and

content. Annals of General Psychiatry 2010 9(Suppl 1):S46.
Submit your next manuscript to BioMed Central and take full advantage of:

- Convenient online submission

- Thorough peer review

- No space constraints or color figure charges

- Immediate publication on acceptance

- Inclusion in PubMed, CAS, Scopus and Google Scholar

- Research which is freely available for redistribution 